\title{
Patch Dosage Form
}

National Cancer Institute

\section{Source}

National Cancer Institute. Patch Dosage Form. NCI Thesaurus. Code C42968.

A solid composed of an impermeable occlusive backing and a formulation matrix in which the active and/or inert ing redient(s) are dissolved or dispersed; possibly includes an adhesive layer. 